\title{
ILCEA
}

Revue de l'Institut des langues et cultures

d'Europe, Amérique, Afrique, Asie et Australie

$46 \mid 2022$

Refuges identitaires numériques

\section{Queering the Lebanese Instagram: Reimagining}

Futurity

L'Instagram libanais au prisme du queer : réimaginer l'avenir

\section{Abed Al Wahab Kassir}

\section{OpenEdition}

\section{Journals}

Electronic version

URL: https://journals.openedition.org/ilcea/14140

DOI: $10.4000 /$ ilcea. 14140

ISSN: 2101-0609

\section{Publisher}

UGA Éditions/Université Grenoble Alpes

\section{Printed version}

ISBN: 978-2-37747-331-1

ISSN: $1639-6073$

\section{Electronic reference}

Abed Al Wahab Kassir, "Queering the Lebanese Instagram: Reimagining Futurity ", ILCEA [Online], 46 | 2022, Online since 02 March 2022, connection on 04 March 2022. URL: http:// journals.openedition.org/ilcea/14140 ; DOI: https://doi.org/10.4000/ilcea.14140

This text was automatically generated on 4 March 2022

(C) ILCEA 


\title{
Queering the Lebanese Instagram: Reimagining Futurity
}

\author{
L'Instagram libanais au prisme du queer : réimaginer l'avenir
}

\author{
Abed Al Wahab Kassir
}

\section{Introduction}

1 In 2019, 85\% of Lebanese opposed homosexuality (Pew Research Center, 2020) in a country where same-sex attraction is still conceived as a deviation, sickness, and moral corruption. Nevertheless, more queer initiatives are rising, particularly within the virtual world, as the Internet altered how do we view the whole world, insinuating more tolerance towards non-normative gender identities (Correll, 1995; Campbell, 2004; Fox, 2007; Light, Fletcher, \& Adam, 2008; Mowlabocus, 2010). For Chaarani, the Lebanese queer community exists more as a virtual crowd than a concrete physical group. (Chaarani, 2009)

2 On Instagram, a growing number of accounts come to challenge the heteronormative power reclaiming queer representations and voices. Mathew Gagne describes being online as the "beginning of a meditative process in the consolidation of queer self where digital media and queer culture intersect and produce each other." (Gagné, 2012)

3 As the line separating the virtual world from the physical one has become blurred, merging both online with everyday identity (Fox, 2007), I analyze how the accounts contribute to the construction of the Lebanese queer identity.

\section{Contextualizing Beirut}

4 Institutionally, article 534 of the Lebanese penal code punishes sexual acts that are "contrary to nature" up to one year in prison. Although several legal wins were recorded in the Lebanese courts ruling in favor of sexual liberties and equalities (The 
Legal Agenda, 2017), the state still relies on the above article to brutally crackdown on queer spaces and events, limiting queer presence and resistance. (Human Rights Watch, 2017)

Moreover, the existence of few gay-friendly spaces in Beirut has been misinterpreted by Western media, which portrayed the city as "the gay Arab paradise" (Healy, 2009). Such labeling does not only dismiss the daily struggle that Lebanese queer face (Moussawi, 2013) but serves the state semi "Homonational" (Puar, 2007) policy in spreading the narratives of Beirut exceptionalism. (Moussawi, 2020)

6 As modernity has been linked to sexual freedom (Butler, 2010), and gay visibility turns to be an essential indicator of liberties (Manalansan, 1995; Duggan, 2020; Butler, 2010), the Lebanese government promoted Beirut as the place of sexual freedom to attract capital money, foreign investments, and tourism to rebuild the country after the 15 years of civil war. (Masri, 2010; Moussawi, 2018)

7 Bringing these neoliberal policies into action, the system permitted the existence of queer places and spaces, mainly clubs and pubs, which mirror such exceptional image while securing the limitation of any kind of activism that might disturb the heteronormative patriarchal nature of the system.

In the streets of Beirut, the LGBTQ community still faces various kinds of harassment, making them one of the vulnerable groups in the country.

\section{Methods}

9 I choose to focus on Instagram and not another social/dating app that is catered specificity to the LGBTQ community due to the fact that while the latter is much safer, choosing to advocate on platforms that are public, openly accessed, and predominated by heterosexuals and normative codes insinuates the binging of a new queer era that diverts from the long hiding history. It signals a change that breaks free from fear, taboos and stigma.

10 I closely examine two Instagram queer accounts: Artqueerhabibi and Takweer, locating how the content of their posts contributes to the construction of the new Lebanese queer identity. My selection was primarily based on the different strategies each account employs to address its audience and secondly on the content. Although more queer artistic Instagram accounts continue to appear, ArtQueerHabibi remains distinct due to the highly imaginative and creative standards where its contents bravely and unapologetically mirror queerness.

11 To fully comprehend how the two Instagram accounts are contributing to the Lebanese queer identity modulation, I conduct a content analysis of the posts analyzing the meanings and implications they are producing.

12 I move beyond both the traditional mainstream representation of queer victimization, which depicts the daily queer struggle in the Arab World, and the White Western narratives of queerness and modernity, presenting a de-colonized reading of the effects that both Instagram accounts are creating. I also depart from the homonormative (Duggan, 2020) binaries of pride vs. shame and out vs. the closet. Instead, focusing on how the posts are negotiating cultural realities to produce queer futurity. 
13 I rely on Michael Warner's (2002) analysis of community constructions through texts and productions, as readers associate and identify with each other, forming a new bounding and a sense of belonging (Warner, 2002). Wendy Chun's "Homophily" also remains important as she refuses the claim that the Internet is an open space where everyone connects; instead, she argues that similarities are what breeds connections.

14 It is also important to clarify that although the radical visibilities that the illustrations suggest are still far from being present realities, I conceive the posts according to what Sara Ahmed refers to as "marks" and "traces" as they allow the viewers to "associate the experience of having an emotion with the very effect of one surface upon another, an effect that leaves its mark or trace." (Ahmad, 2004: 6) These traces accumulate to build "queer worlding" that is "not a state of being, but rather one of becoming" (Manalasan, 2013: 571).

\section{Artqueerhabibi}

With 90,000 followers and 107 posts, as of May 2021, Artqueerhabibi relies on the medium of arts illustration to reimagine a queer version of the Arabic cities. The artist who keeps his identity hidden for safety reasons said to Plastik magazine that his primary purpose is to spread love and acceptance through raising awareness, breaking stigmas, and pushing queer visibility forward (Plastik, 2019). The illustrations mainly depict famous locations, such as the Egyptian pyramids, a metro station, a famous restaurant in Beirut, with a queer twist through adding people, actions, and objects that defy gender binary and compulsory normativity.

Inspired by his own experience as a queer person residing in Beirut, his friends, the Lebanese revolution (2019), Beirut Drag queens, and other famous queer figures in the Arab world, the artist fills his page with pictures depicting queer romance, sex, desire, and non-normative bodies. In his drawings, we see men sharing flirtatious gaze, women hugging, men kissing at the airport, same-sex romance, and same-sex sexual encounters.

Navigating the public sphere has always been surrounded by difficulties and fear, especially for non-normative bodies and trans women who are ridiculed, harassed, and excluded. (Merabet, 2014; Moussawi, 2020) Artqueerhabibi comes to mess things up, distrusting the normative coding of the bodies, objects, and spaces. It defies the geographical, safety, and cultural limits where queers unapologetically take the streets, expressing their presence, affection, and erotic desire. The pictures recall Michael Warner's definition of queerness that is to be conceived as what "let loose the rather wild smell of sexual rut to permeate, invade and stink up." (Warner as cited in Manalansan, 2013) 
Figure 1. - Love (Artqueerhabibi, 2018).

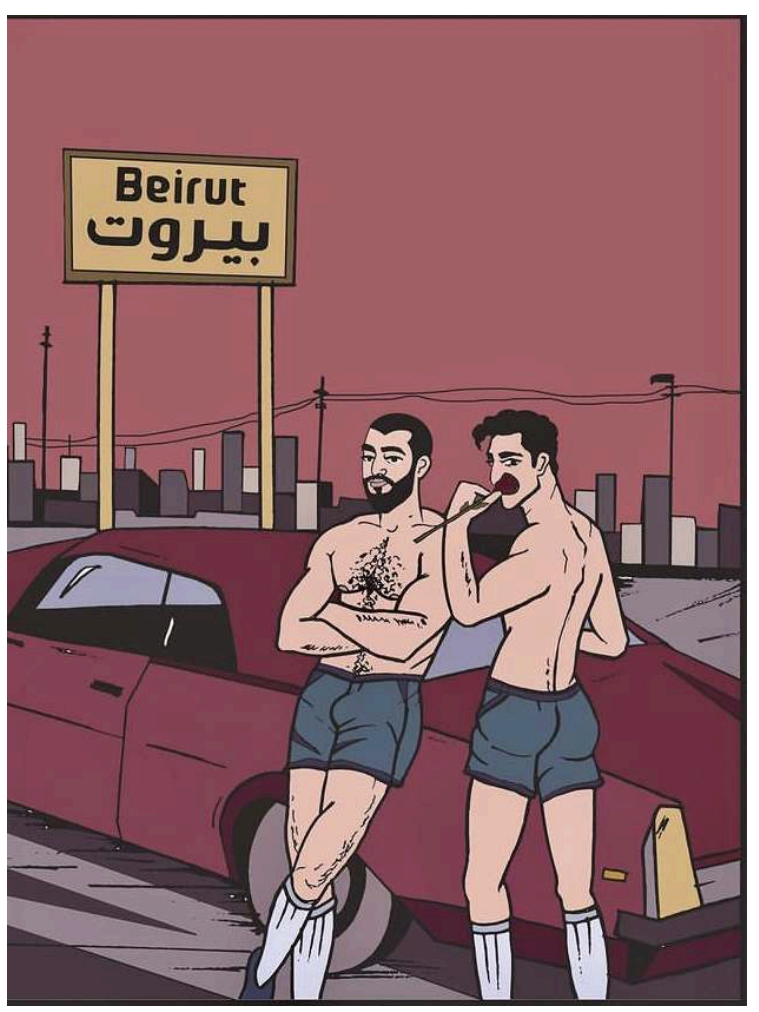

Through kissing, romance, the gay gaze, the fetishized gaze, the artist is constructing what Martin Manalansan describes as "queer worlding," which "involve the creation of material and semantic knowledge about space that is dependent on structural locations and power locations." (Manalansan, 2013: 569) Sexuality, especially same-sex desire that has permanently been restricted to the private sphere is now the city's primary residence where bodies, identities, and both queer sensuality and sexuality are unchained.

\section{Spaces as the extensions of the bodies}

The streets, the train station, the airport, the sidewalk, and the nightclub are now taking a new life as queer subjectivities manifest themselves within. Sara Ahmed describes the space as a "second skin that unfolds in the folds of the body." (Ahmed, 2006: 5) The proximity and distances between the bodies and both the objects and the places reorient spaces with new meanings.

The terror that continuously escorts queer bodies had collapsed. There is no need anymore to adapt strategies to pass safely within the public sphere (Moussawi, 2020). On the contrary, the queer inhabitance is creating a new time and space outside the constraints of heteronormativity. The "here" and "now" are packed with happiness, love, eroticism, and desire. Queers bodies are not anymore the strange aliens that make heterosexuals look more humans (Ahmed, 2000); they are organically harmonizing with space, re-identifying the new cities that are free from exclusion.

21 Filling spaces with love and desire projects hope. Both feelings promise safety, security, and connection pushing the body into new directions within the space. Projecting queer love means overcoming the impossibility while defeating the cultural barriers, 
homophobia, and patriarchy. To perform romance is to counter the heteronormative interpretation of queerness as deviation and sickness where there are no happy endings. The posts mirror happy stories that are craved by the silence of the image, "the many silence that are an integral part of the strategies that underlie and permeate discourse" (Sedgwick citing Foucault, 1990: 3).

The emotions the posts raise and expressed through the follower's comments are to be read as construction of queer embodiment and identity. Sara Ahmed stresses the impact of how emotions, along with repetition, create queer bodies. Hence, building on Butler's (1990) and Ahmed's (2004) narratives, I argue that through repetition; this account is not only reorienting the queer self but also normalizing the non-hegemonic gender concepts and performances.

\section{Building one community}

Wendy Chun's concept of "Homophily" counters the claim that the Internet is an open space that brings everyone closer. On the contrary, she shows that similarities are what breed connections and bonds in the name of comfort, predictability, and common sense (Chun, 2016). Homophily which she defines as "love as the love of the same" (Chun, 2016: 62), maps new connections based on resemblance making those who share common things "virtual neighbors" (Chun, 2018). For the oppressed queer minorities, such neighborhood acts as a vital resistance strategy opening up possibilities for social ties that breaks self-isolation while promising companionship, intimacy, reassurance, sense of belonging, self-esteem, and most importantly, improve mental health outcomes (Doty, Willoughby, Lindahl, \& Malik, 2010; Hatzenbuehler, 2011; Heaney \& Israel, 2008; Ryan, Huebner, Diaz, \& Sanchez, 2009).

Artqueerhabibi reinforces the love of the self, allowing its members to post comments, follow each other, share lived experiences and stories, and extend the social networks in a culture that teaches queers to hide and hate their stigmatized and shameful self/ identity.

The post's emotional appeal generates a sense of belonging as it produces connections, common understanding, and empathy, specifically between members who share a common understanding of marginalization and dehumanization. (Cvetkovich, 2003: 38) Warner describes how the circulation of reflections and feelings produces what he calls the "public" and "counter-public," which are organized entities that gather on the basis of common recognition, engagement, and interaction with the content. (Warner, 2002: 12) The public turns to be taking part in constructing and circulating the new uprising queer identity.

\section{Demarginalizing the marginalized within their own community}

Ghassan Moussawi (2018) argues that access to queer circles, spaces, and establishments is governed by exclusions based on class privileges, gender normativity, education privileges, and cultural capital (fluency in English or French) (Moussawi, 2018). Building on Chun's "Homophily" theory, I argue that the medium (Instagram) not only minimize such differences as the connections and the interactions are mostly 
based on queer subjectivity and gender identity, but also erases additional limitations such as geographic locations, the fear of being outed or seen in specific locations, and cultural capital as the posts are written in Arabic and English.

Marginalizing the other within the community is also tackled within the content of the posts as they defy what Tom Roach calls the "ugly truth" of effemenophobia, racism, sexism, patriarchal masculinity, and classism that dominates queer communities. (Roach, 2015)

Figure 2. - Nezel el Samak (Artqueerhabibi, 2019).

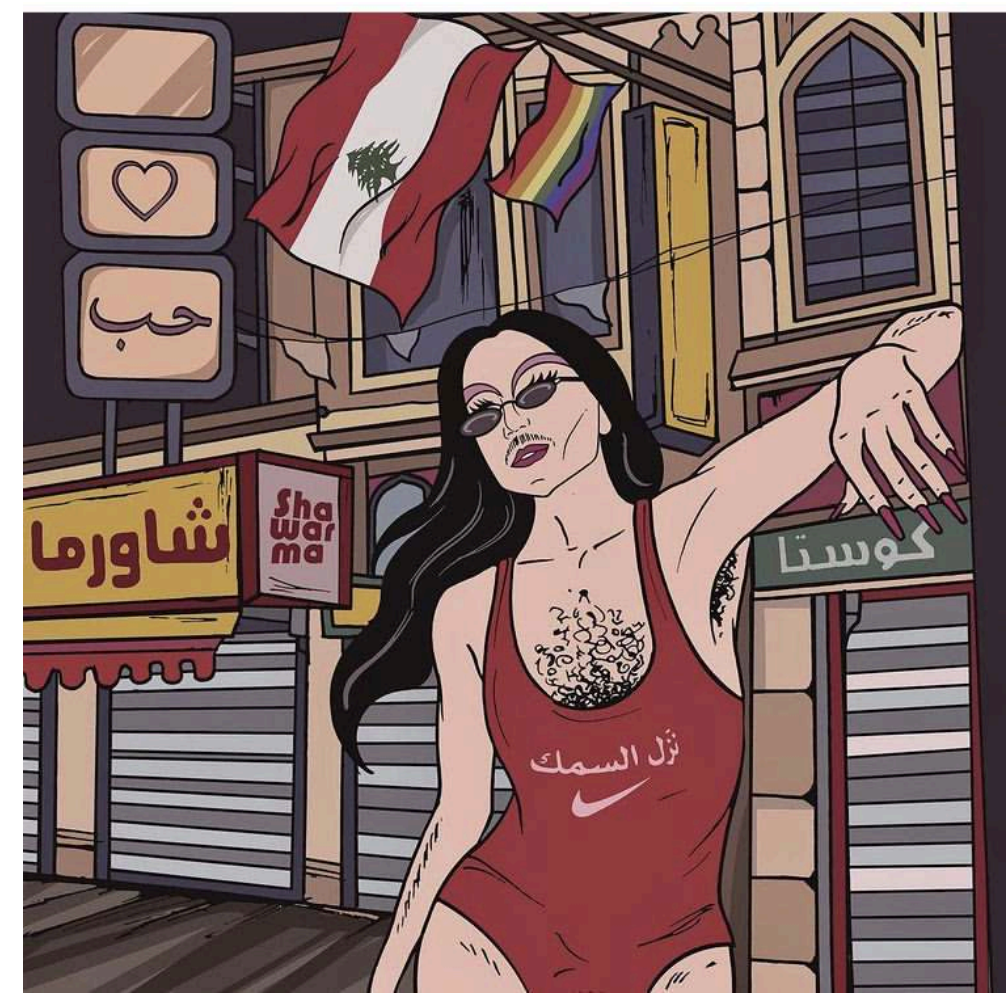

Gay men remain occupied with traditional notions of masculinity to "pass" as "normal" males while expressing negative attitudes towards effeminate behaviors in other gay males. To be desired, the body must be inscribed within the heteronormative code or what Butler calls the "heterosexual matrix" (Butler, 1990: 151) of masculinity or as repeatedly expressed on dating websites and applications: "straight-acting/nonfeminine" (Clarkson, 2008).

In his ethnographic analysis of the queer community in Beirut, Sofian Merabet (2014) analyzes what he refers to as the "homosexual homophobia" that is practiced towards effeminate men and transsexual women inside gay places. (Merabet, 2014) Ghassan Moussawi also speaks of isolation that non-cis-males experience since being seen with a feminine body means being "dragged out" of the closet. (Moussawi, 2020)

Artqueerhabibi challenges this gender normative understanding breaking free from masculine toxic conceptualization of the male body through posts that celebrate the male femininity. Cross-dressing, male in a voguing position, male belly dancing, drag queens, and travesties are all illustrated, creating spaces for the followers to safely express emotional and embodiment vulnerability beyond the bounds of hegemony. It is mirroring a daily internal struggle that queer Arabs continue to live with as they 
constantly practice "masculinity consciousness," ensuring that they pass as "straightlooking men." The fair presentation of everyone, including the most stigmatized and marginalized bodies within their community, projects a regeneration of a community that is free from exclusions. Warner writes: "only when this indignity of sex is spread around the room, leaving no one out, and in fact binding people together, that it begins to resemble the dignity of the human." (Warner, 1999: 31)

31 I read the posts as an open invitation to rethink the impact of masculine hegemony and evaluate the self while engaging the followers with an embodiment of unconstrained masculinity that deconstructs the source of toxic expression that limits them.

The positive comments posted on such pictures reflect the slipping of power (Kimmel, 2012) from the hands of hegemony and traditional notions of masculinity towards more liberal and unrestricted gender performances. The comments reflect potential new dynamics where cis-males and effeminate men are not relating anymore to each other within the term of dominant versus subordinate. On the contrary, the account reflects the construction of a holistic approach of masculinity that embraces a more affirming sense of self and embodies functional masculinity that operates outside the bounds of hegemony.

Deconstructing classism is also tackled within the posts. As I mentioned above, Ghassan Moussawi presents the importance of social classes in shaping access and experiences in queer spaces and circles. Some illustrations in the account mess up the long history of Lebanese classism and class demarcation. Here love and desire are what matters. The inter-class queer encounter becomes the norm. In one of the posts, a man is kissing a taxi driver, a "low-class" profession within the Lebanese socio-economical standers. Another post shows a man bringing a flower to his same-sex lover that sells Falafel, traditional food known as the "dish of the poor." The posts are undoing classism, demolishing the continuous "White middle-class" understanding of queerness that dismisses the working-class experiences.

\section{Takweer}

34 Takweer is another Instagram account that was created on the the 11th of September 2019. In Arabic, Takweer means to make something spherical, as a new version of the spherical world that we live in. It also sounds the same as the English word "queer." With 5.247 followers and 67 posts, as of May 2021, the owner describes it as a place to explore queer narratives in Arab history and popular culture. The posts document various practices and gender identities, uncovering queer historical figures, artists who defied gender norms, non-normative cultural habits, and homosexual TV and movie characters across centuries.

Posts of Effeminacy, non-binary, Transsexuality, Drag queens, cross-dressing, and homoerotics are all displayed. In an interview with Huck magazine, Marwan Kaabour, the founder of the account, stated that the main motive behind the account is to uncover queer Arabic experiences of those who came before us "shedding light on the pre-colonial narratives, so we can feel that our existence is a continuity of one that stretches way back." (Huck magazine, 2021)

On the contrary to the previous account, Takweer takes us on a journey to the past as it relies on archiving strategies to bring queer rhetoric forward. Jack Halberstam 
describes the importance of queer archiving writing: "Archive is not simply a repository, it is also a theory of cultural relevance, a construction of collective memory, and a complex record of queer activity." (Halberstam, 2005: 169-170). For Foucault, an archive is not just a material site filled with documents but as a space of enunciation. (Foucault, 1972) To archive is to revive wiped realities that had been intentionally erased either by the European colonial past (El- Rouyaheb, 2005) or due to the rise of Islamist fundamentalism. ${ }^{1}$ (Dalacoura, 2014) The images and videos posted turn to be "evidence of existence" of the long queer history and customary practices within the Arab culture. They counter the narratives around queer "alienated" origins and the claim that queerness is earthier a Western product imported to the Arab World to destroy Arab moral values (Whitaker, 2006; Habibi, 2007; Dalacoura, 2014; Amer, 2012), or even a new form of cultural colonization where gays are intruders and victims of Western Imperialism. (Massad, 2007)

On September 24th, 2007, in a questions/answers session at Colombia University, the previous Iranian president Ahmadi Najad stated: "In Iran, we do not have homosexuals like in your country... In Iran we do not have this phenomenon, I do not know who told you we have it." (Goldman, 2009)

The anthropologist Samar Habib explains the denial of the homosexual presence in the Arab World as it comes from colonial imposition in which Arabs define themselves through opposing the West. "So if the oppressor (the West) has gays, then we do not have them. If they do not execute, we do. That is how we define ourselves through the relations of the other." (Salma, Nayrouz, \& Ghaida Moussa, 2011: 10)

The posts "as evidence" also counter the Western "Orientalist" discourse (Said, 1978) of the "Homophobic Muslim" narratives depicting the Arab race as inherently homophobic and sexist and Muslims as direct threads to sexual freedoms. The evidences drop the Western conclusions that present Arab queers as not "queer enough" as they do not conform to the neoliberal codes of modern queerness, as well as their fate of living in continuous fear and oppression.

Takweer proves the opposite. In one of the posts, the creator presents a collection of pictures titled "The Khawal Dancers," documenting the "Khawalat" or the male transvestite dancers who took part, until the late 1950s, in popular festivals and celebrations besides being a standard character in many films. Garay Menicucci coded their presence as "to imply the existence of a homosexual subculture or transgressive sexuality in general... They also often possess uncanny wit, a cynical sense of pragmatic realism, and personal integrity lacking in the conventional heterosexual characters that are surrounding them." (Menicucci, 1998)

41 Portraying Arab local queer figures that the audience can culturally relate to in such a positive context leaves its impact on the viewer's self-perception. Kivel and Kleiber explain how queer individuals rely on various media sources to learn about their identity by searching for individuals to whom they can relate. (Kivel \& Kleiber, 2000) Studies also showed how non-heterosexuals who model after successful media figures/ role models they share similarities with, develop a stronger sense of self-efficiency. (Ochman, 1996; Cheung \& Yue, 2003; Hammack, 2005; Lockwood, 2006)

One of the remarkable posts the account presents are pictures from "Miss Hanafi" (1954), an old black and white Egyptian comedy movie inspired by the story of the first Egyptian transsexuals. Hanafi, the main character, portrays a misogynist male authority controlling every aspect of his fiance's life. Before the wedding, he was admitted to the 
hospital where accidentally, the doctors perform a "sex reassignment surgery," turning him into a female character named Fifi. The post comments on the movie writing:

The film showed a relatively progressive view of gender reassignment, as it did not criminalize it or poke fun at it, but rather show it as a "normal" issue, and was treated as such by the film characters. In a very insightful dialogue in the film, the $x$ fiancé reminds Fifi: There is no shame in a man becoming a woman or a woman becoming a man. The shame is men's selfishness, how they deprive girls of education and turn their life into the prison that we live in. (Takweer, 2021)

These progressive archived materials are to conceived as essentials that secure meanings of the past (Derrida,1995) and as sites of knowledge and power that produce historical truths. (Foucault, 1972)

However, archives not only narrate the past but also inform the present as the content comes back to life through discussions and responses. For Derrida, Archives are sites to "question of the future itself, the question of a response, of promise and of a responsibility for tomorrow." (Derrida, 1995: 37)

Arab queer histories are the starting point for any future construction of local queer identities away from the Euro-American homonormative understanding of gender, queer liberation, and modernity. Pierre Bourdieu explains how history hunts us to become "inscribed in our dispositions: how we see ourselves and the extent we can envision alternative outcomes to those histories" (Bourdieu, 1990: 57); in other words, he suggests that our habitus/bodies are formed through the ways we embody history. (Bourdieu, 1990)

\section{Conclusion}

Both Artqueerhabibi and Takweer contribute to the construction of the new Lebanese queer identity moving the discourse from the private to the public sphere while raising a collective and wider sense for the "possibilities of being." The representation that they suggest is rooted within the Lebanese local cultural realities and specificities breaking free from both the Western and global understanding of gender and the Western orientalist discourse that depicts the Arabic world as a place of total oppression.

The representation is complicating the understanding of identities that usually rest on the binaries of "in the closet" vs. "outside the closet," "out" vs. "oppressed," and pride vs. shame. The work created by queers to other queers who share the same struggle establishes a heteroglossic narrative that counters the normative discourse projecting a queer common futurist perspective.

both Michael Warner's (2002) analysis of community constructions through circulating discourse and Wendy Chun's "Homophily" where similarities bring connections, as a focus of my analysis, I argued that the discussions, emotions, and the reactions the posts raise are producing an organized entity that shares new meanings, beliefs, and self-understanding. The uprising queer politics turn with time and repetition to form new normalities. What started as an artistic attempt had turned to be a site of collective activism and community building.

By examining Artqueerhabibi's posts, I argued that the account is reorienting the public spaces by giving them new shapes and meanings that are packed with familiarities and safety (Ahmed, 2006). They end the long history of hiding and 
escaping their ender realities while reimagining the city away from nostalgia, sadness, loss, and lust. The new realities are reversing the traditional queer immigration where queer Arabs are now moving towards their cities.

The content of the posts is also touching upon the collective being as a community that is free from oppression, hierarchies, and power dynamics based on an obsession with masculine normative performances and social classes that respectively control the accesses to queer circles and places. Artqueerhabibi resists the pressure to conform to normative and social class performances by empowering and celebrating effeminacy and anti-classism.

With Takweer I shed light on how archiving is reopening discussion around queer Arab history, leaving its impact on both the present and the future. The posts offer a new "structure of feelings" (Williams, 1977) in a crucial moment of queer becoming. They are the evidence of the long Arabic queer history challenging both local claims about the foreign origin of homosexuality and the Western assertions in which they conceive Arab/Muslims as not queer enough. Building on Derrida and Bourdieu, I also showed how reinterpreting the past that hunts shape the queer future embodiment.

In conclusion, the production of queer love and the archiving of queer historical power and success replace the long traditional "generative of failure" (Halberstam, 2005) by connecting, achieving, and reproducing power.

Both accounts move beyond "the promises of happiness" (Ahmed, 2010) to imagine the possibilities of being. The mess that they create is discomforting heteronormativity constituting a new reading for potential queer Arab identity and community building.

As this paper was mainly interested in the production of Lebanese queer identity through Instagram's posts, It remains important for future studies to investigate the reception within the Lebanese cultural context and between queer members paying more considerable attention to the subjectivities produced by the followers, mainly their comments and reactions on the posts.

\section{BIBLIOGRAPHY}

ABC NEWS (2009), Ahmadinejad: No Gays, No Oppression of Women in Iran, Retrieved from <https:// abcnews.go.com/US/story?id=3642673>.

AHMED Sara (2000), Strange Encounters: Embodied Others in Post-Coloniality, Routledge.

AHMED Sara (2006), Queer Phenomenology: Orientations, objects, others, Durham: Duke University Press.

AHMED Sara (2010), The Promise of Happiness, Durham: Duke University Press.

AHMED Sara (2012), On being included: Racism and diversity in institutional life, Durham: Duke University Press.

AHMED Sara (2014), The cultural politics of emotion (2nd edition), Edinburgh University Press. 
AMER Sahar (2012), "Naming to Empower: Lesbianism in the Arab Islamicate World Today", Journal of Lesbians Studies, 16(4), 381-397.

BOURDIEU Pierre (1990), The Logic of Practice, Alto: Stanford University Press.

BUTLER Judith (1990), Gender Trouble: Feminism and the Subversion of Identity, New York: Routledge.

BUTLER Judith (2010), Frames of war: When is life grievable? London, UK: Verso.

CAMPBELL John Edward (2004), Getting it Online: Cyberspace, Gay Male Sexuality, and Embodied Difference, Binghamton, NY: The Harrington Park Press.

ChAARANi James (2009), “Lebanon: At Best a Virtual Gay Community”, Gay \& Lesbian Review Worldwide, 16(2).

CHeung Chau-Kiu, \& Yue Xiao Dong (2003), “Adolescent modeling after luminary and star idols and development of self-efficacy", International Journal of Adolescence and Youth, 11(3), 251-267.

CHUN Wendy Hui Kyong (2016), “Big data as drama”, Elh, 83(2), 363-382.

CHUN Wendy Hui Kyong (2018), “Querying Homophily. In Apprich, Clemens”, F. Cramer, W. H. K. Chun, \& H. Steyer (eds), Pattern Discrimination, Lüneburg: meson press, 59-97.

CLARKSON Jay (2008), “The Limitations of the Discourse of Norms: Gay Visibility and Degrees of Transgression", Journal of Communication Inquiry, 32(4): 368-82.

CORRELL Shelley (1995), “The ethnography of an electronic bar: The lesbian cafe", Journal of Contemporary Ethnography, 24, 270-298.

CVETKOVICH Ann (2003), An archive of feelings: Trauma, sexuality, and lesbian public cultures, Durham: Duke University Press.

DALACOURA Katerina (2014), "Homosexuality as cultural battleground in the Middle East: culture and postcolonial international theory", Third World Quarterly, 35(7), 1290-1306.

DERRIDA Jacques (1996), Archive Fever: A Freudian Impression, Chicago University Press.

Doty Nathan Daniel, Willoughby Brian L. B., LindAhl Kristin M., \& MALIK Neena M. (2010), "Sexuality-related social support among lesbian, gay, and bisexual youth", Journal of Youth and Adolescence, 39(10), 1134-1147.

Duggan Lisa (2020), "The New Homonormativity: The Sexual Politics of Neoliberalism", R. Castronovo, D. D. Nelson \& D. E. Pease (eds), Materializing Democracy - Toward a Revitalized Cultural Politics, Durham: Duke University Press, 175-194.

EL-RouAYHEB Khaled (2005), Before homosexuality in the Arab-Islamic world, 1500-1800, Chicago: The University of Chicago Press.

FouCAult Michel (1972), The Archaeology of Knowledge (S. Smith, trans.), New York: Pantheon Books.

Fox Ragan (2007), Gays in (Cyber-) Space: Online Performances of Gay Identity, AV Akademikerverlag. GAGNÉ Mathew (2012), “Queer Beirut Online: The Participation of Men in Gayromeo.Com”, Journal of Middle East Women's Studies, 8(3), 113-137.

GEORGIS Dina (2013), “Thinking past pride: Queer Arab shame in bareed mista3jil”, International Journal of Middle East Studies, 45(2), 233-251.

HАВIB Samar (2007), Female Homosexuality in the Middle East: Histories and Representations, New York: Routledge. 
HALBERSTAM Judith (2005), In a Queer Time and Place: Transgender Bodies, Subcultural Lives, New York: New York University Press.

HAMмACK Phillip L. (2005), “The life course development of human sexual orientation: An integrative paradigm", Human Development, 48, 267-290.

HATZENBUEhLER Mark L. (2011), “The social environment and suicide attempts in lesbian, gay, and bisexual youth", Pediatrics (Evanston), 127(5), 896-903.

HEALY Patrick (2009), "Beirut, the Provincetown of the Middle East", The New York Times (Travel Section), <http://travel.nytimes.com/2009/08/02/travel/02gaybeirut.html>.

HEANEY Catherine A., \& ISRAEl Barbara A. (2008), "Social networks and social support”, K. Glanz, B. K. Rimer \& K. Viswanath (eds), Health behavior and health education: Theory, research, and practice ( $4^{\text {th }}$ ed.), Jossey-Bass, <https://psycnet.apa.org/record/2008-17146-000>.

HUMAN RIGHTS WATCH (2017), Lebanon: Events of 2017, retrieved from: <https://www.hrw.org/worldreport/2017/country-chapters/lebanon>.

Kimmel Michael S. (2012), Manhood in America: A Cultural History, Oxford University Press.

KIVEL Beth D., KLEIBER Douglas A. (2000), "Leisure in the identity formation of Lesbian/Gay youth: Personal, but not social”, Leisure Sciences, 22(4), 215-232.

LiGHT Ben, FleTCHER Gordon, \& ADAM Alison (2008), "Gay men, Gaydar and the commodification of difference", Information Technology and People, 21, 300-314.

LocKWOOD Penelope (2006), "Someone like me can be successful: Do college students need samegender role models?", Psychology of Women Quarterly, 30, 36-46.

MANALANSAN Martin F. (1995), "In the shadows of Stonewall: Examining gay transnational politics and the diasporic dilemma", Q: A Journal of Lesbian and Gay Studies, 2, 425-438.

MANALANSAN Martin F. (2013), "Queer worldings: The messy art of being global in Manila and New York: Queer worldings: Manila and New York", Antipode, 47(3), 566-575.

MASRI Ghada (2009), "Resurrecting Phoenicia: Tourist landscapes and national identity in the heart of the Lebanese capital", R. Maitland, \& B. Ritchie (eds), City Tourism: National Capital Perspectives, 225-238.

MASSAD Joseph A. (2007), Desiring Arabs, Chicago: The University of Chicago Press.

Menicucci Garay (1998), “Unlocking the Arab Celluloid Closet: Homosexuality in Egyptian Film”, Middle East Report (206), 32-36.

MERABET Sofian (2014), Queer Beirut, Austin: University of Texas Press.

Moussawi Ghassan (2013), “Queering Beirut, the 'Paris of the Middle East': fractal Orientalism and essentialized masculinities in contemporary gay travelogues", Gender, Place \& Culture, 20(7), 858875.

MousSAWI Ghassan (2018), "Queer exceptionalism and exclusion: Cosmopolitanism and inequalities in 'gay-friendly' Beirut”, The Sociological Review (Keele), 66(1), 174-190.

MoussaWI Ghassan (2020), Disruptive situations: Fractal orientalism and queer strategies in Beirut, Philadelphia: Temple University Press.

Mowlabocus Sharif (2010), Gaydar Culture: Gay men, technology and embodiment in the digital age, Farnham, UK: Ashgate. 
MuÑOZ José Esteban (1999), Disidentifications: Queers of Color and the Performance of Politics, Minneapolis: University of Minnesota Press.

NASR Nour \& ZEIDAN Tarek (2015), “As Long as They Stay Away: Exploring Lebanese Attitudes Towards Sexualities and Gender Identities. Arab Foundation for Freedoms and Equality", retrieved from: <http://gsrc-mena.org/gsrc/wp-content/uploads/2015/12/Report-highresolution1.pdf>.

OCHMAN Jan M. (1996), “The effects of nongender-role stereotyped, same-sex role models in storybooks on the self-esteem of children in grade three", Sex Roles, 35, 711-736.

PUAR Jasbir (2013), “Rethinking homonationalism”, International Journal of Middle East Studies, 45(2), 336-339.

Pew Research Center (2020), The Global Divide on Homosexuality Persists, retrieved from <https:// www.pewresearch.org/global/2020/06/25/global-divide-on-homosexuality-persists/>.

RoACH Tom (2015), “Becoming fungible: Queer intimacies in social media”, Qui Parle: Critical Humanities and Social Sciences, 23(2), 55-87.

RYAN Caitlin, HuEBNER David, DiAZ Rafael M., \& SANCHEZ Jorge (2009), "Family rejection as a predictor of negative health outcomes in White and Latino lesbian, gay, and bisexual young adults", Pediatrics, 123, 346-352.

SAID Edward W. (1978), Orientalism, Pantheon Books.

Salma A. A., Nayrouz Abu Hatoum, \& GHaida Moussa (2011), "Reflections on Queerness in the Arab World: An Interview with Samar Habib", Feminist Approaches in Culture and Politics, 15, Toronto, <http://www.feministyaklasimlar.org/wp-content/uploads/2013/07/

AnInterviewwithSamarHabib.pdf>.

SEDGWICK Eve K. (1990), Epistemology of the Closet, University of California Press.

WARNER Michael (1999), The Trouble with Normal: Sex, politics, and the ethics of queer life, Harvard University Press.

WARNER Michael (2002), Publics and Counterpublics, New York; Cambridge, Mass.: MIT Press.

WHITAKER Brian (2006), Unspeakable Love: Gay and lesbian life in the middle east, Saqi.

WiLliAMS Raymond (1977), Marxism and Literature, Oxford: Oxford University Press.

\section{NOTES}

1. Hamas Islamic resistance movement in Palestine, Al- Qaeda, the Egyptian Islamic Brothers, and the Iranian Islamic Revolution are the most famous Islamic fundamentalist groups formed in the 1970s and 1980s. 


\section{ABSTRACTS}

Social media platforms have become an important arena for sexual politics equipping queers with safe alternative spaces while pushing their visibility and connectivity forward. My article examines two Lebanese queer Instagram accounts analyzing their contribution to the current construction of Lebanese queer identity. I examine how the tactic employed by each account is generating queer realities, meaning, and embodiment. While "Artqueerhabibi," use the medium of comics, to reimagine a different queer reality creating a sense of belonging to the uprising community, "Takweer" archive queer Arab history and popular culture. The archive not only revives the long wiped queer history but also informs both the present and the future as the content comes back to life through discussions and responses.

Queer here is used both as an identity and an adjective to describe how both accounts are unsettling the normative understanding of sexuality and gender expression, besides raising new meanings and possibilities for local sexual politics.

Les réseaux sociaux sont devenus une arène importante pour la politique sexuelle. Ils offrent aux homosexuels des espaces alternatifs sûrs tout en faisant évoluer les visibilités et les connectivités. Cet article étudie deux comptes Instagram homosexuels libanais. Il analyse leur contribution à la construction récente d'une identité libanaise queer. Cette étude vise à montrer comment la stratégie employée par chaque compte génère des réalités queer et d'autres significations et incarnations queer. Tandis que le compte «Artqueerhabibi » utilise la bande dessinée comme moyen d'imaginer une nouvelle perception et projection queer dans l'avenir, le «Takweer » archive l'histoire du monde arabe à travers la documentation, l'art et la culture populaire. Ces archives ne font pas seulement revivre l'histoire de l'homosexualité, mais informent également le présent et l'avenir, car le contenu revient à la vie concrète grâce aux discussions et aux réponses.

Le terme « queer » utilisé ici renvoie à la fois à une identité et à un adjectif pour décrire comment les comptes Instagram perturbent la compréhension normative entre la sexualité et l'expression de genre pour soulever de nouvelles significations et possibilités pour la politique sexuelle locale.

\section{INDEX}

Keywords: queers, Instagram, gender representation, Lebanon, identity

Mots-clés: queers, Instagram, représentation du genre, Liban, identité

\section{AUTHOR}

\section{ABED AL WAHAB KASSIR}

Department of Communication and Anthropology, Universitat Rovira I Virgili, Campus

Catalunya, A- 331, Av. Catalunya 35, 43002, Tarragona, Spain.

abedalwahab.kassir@estudiants.urv.cat

<https://orcid.org/0000-0001-6111-9943> 